\title{
Dekret Sądu Metropolitalnego w Katowicach z 09.07.2009 w sprawie o nieważność wyroku
}

Ius Matrimoniale 15 (21), 217-220

2010

Artykuł został opracowany do udostępnienia w internecie przez Muzeum Historii Polski w ramach prac podejmowanych na rzecz zapewnienia otwartego, powszechnego i trwałego dostępu do polskiego dorobku naukowego i kulturalnego. Artykuł jest umieszczony w kolekcji cyfrowej bazhum.muzhp.pl, gromadzącej zawartość polskich czasopism humanistycznych i społecznych.

Tekst jest udostępniony do wykorzystania w ramach dozwolonego użytku. 


\section{DEKRET SĄDU METROPOLITALNEGO W KATOWICACH Z 09.07.2009 W SPRAWIE O NIEWAŻNOŚĆ WYROKU}

Sąd Metropolitalny w Katowicach w składzie kolegialnym (...) rozpatrywał skargę wniesioną 4.6.2009 przez AP, pozwanego w sprawie o nieważność małżeństwa $\mathrm{BB}$ - AP, o nieważność wyroku wydanego w tejże sprawie w III Instancji przez Sąd Metropolitalny 20.09.2005.

Na posiedzeniu dnia 9.7.2009 Sąd postanowił skargę oddalić.

\section{Uzasadnienie}

1. Sprawy o nieważność wyroku „mogą być załatwione według przepisów odnoszących się do ustnego procesu spornego" (kan. 1627). Tym samym znalazła ustawowe potwierdzenie opinia, że w sprawach o nieważność wyroku ,przebieg postępowania sądowego ma zasadniczo charakter czysto formalny, polegający na sprawdzeniu wysuniętego zarzutu prawnego przeciw zapadłemu wyrokowi" (St. Płodzień, Querela nullitatis..., 162). Zastosowanie takiej procedury pozwala zrezygnować z szeregu formalności i terminów procesowych. Skarga o nieważność wyroku jest bowiem skierowana nie przeciw drugiej stronie procesowej, lecz przeciw Sądowi. Jej rozpatrzenie nie wymaga zawiązania sporu, przedmiotem sprawy jest nieważność wyroku, nie zwołuje się przeto posiedzenia, na którym strony wykładałyby swoje racje, lecz Sąd rozpatruje dowody, które skarżący przedłożył w skardze (kan. 1665). Decyzje Sąd wydaje dekretem.

2. Wedle skarżącego ,w przedmiotowej sprawie zachodzi nieważność usuwalna wyroku, bowiem Sąd Metropolitalny nie dokonał publikacji akt". Trzeba tu najpierw zauważyć, że przyczyny nieważności usuwalnej są wyliczone w kan. 1622 wyczerpująco („dumtaxat” - ,tylko wtedy"), Sądowi nie jest znany akt normatywny, który dopisałby do tych przyczyn jakiekolwiek inne. Nie powiększa też liczby przyczyn nieważności usuwalnej art. 231 instrukcji Dignitas connubii, gdyż po pierwsze - instrukcja nie uzyskała zatwierdzenia Ojca Świętego in forma specifica, a - po wtóre - wydaje się, że inna była ratio legis art. 231 łącznie z ust. $229 \S 3$ (zob. sent. z 28.7.1994 c. Stankiewicz 
- ME 1996, 343 ns.). Pominięcie publikacji akt powoduje nieważność wyroku wtedy, gdy neguje on wzgl. uszczupla prawo do obrony, a wtedy jest to nieważność nieusuwalna, o której w kan. 1620 n. 7 i tylko wtedy skargę o nieważność wyroku można by przedłożyć w ciągu dziesięciu lat od ogłoszenia wyroku. Skarżący nie podnosi zarzutu zanegowanego prawa do obrony, lecz zarzuca pominięcie ,jednego z etapów postępowania”. Budując konstrukcję nieważności usuwalnej pragnie skorzystać z terminu przysługującego na zaskarżenie wyroku o nieważności nieusuwalnej, twierdząc, że „,brak publikacji nie jest objęty zakresem działania kan. 1623 KPK oraz art. 273 Dignitas connubii”. Rzeczywiście, brak publikacji ,jako taki” nie jest objęty kan. 1623, co jednak znaczy - jak to wyłożono wyżej - że nie podpadając pod kan. 1622 nie powoduje (w obecnym stanie prawnym) nieważności usuwalnej. Gdyby ja powodował, podlegałby takim samym regulacjom jak inne przyczyny nieważności usuwalnej, czyli kan. 1623. Skarżący jest rażąco niekonsekwentny, gdy podnosząc zarzut nieważności usuwalnej pragnie skorzystać z terminu przysługującego na zaskarżenie wyroku z powodu nieważności nieusuwalnej.

3. Zupełnie pozbawiony podstaw jest wywód skarżącego, który pisze: „Ściśle formalny charakter ochrony praw w omawianym zakresie prowadzi do stwierdzenia, że jeśli w aktach sprawy znajduje się chociażby jeden dokument, który nie został okazany stronie wskutek braku publikacji akt sprawy, oznacza to, że zapadły wyrok dotknięty jest wadą nieważności usuwalnej”. „Dokument” to w kanonicznym prawie procesowym jeden ze środków dowodowych, o którym w kan. 1539 - 1546. Takich dokumentów nie ma w aktach sprawy III Instancji. W przytoczonym wywodzie skarżącego publikacja akt została potraktowana jako wartość samoistna, a tymczasem ma ona charakter instrumentalny, ma umożliwić obronę. Dlatego należy ją zarządzić ,po zebraniu dowodów" (kan. 1598 §1). Prawo do obrony jest racją norm kanonicznych o publikacji akt (,Necessitas publicationis (...) seu communicationis cum altera parte innititur in necessitate defensionis, quae vix haberi potest quin (utraque pars) cognoverit argumenta adversarii” - (F. Roberti, De processibus..., II, 157. Spośród wielu wyroków rotalnych zob. sent. z 11.5.1994 c. Funghini - ME 1994, 527; dekret z 22.7.1994 c. Giannecchini - ME 1995, 548 - 555).

Absurdalne byłoby domaganie się publikacji akt w sprawie, w której nie przeprowadzono żadnego dowodu i - konsekwentnie - pozbawionej ,akt” stronom nieznanych. Należy przy tym przypomnieć, 
że wykonywanie prawa do obrony winno być wykonywane zgodnie z przepisami prawa („Ius propriae defensionis exercendum non est ad libitum partis, sed ad normam iuris, ut par est" - Najwyższy Trybunał Sygnatury Apostolskiej, dekret z 1.6.1985, cyt. ME 1994, 552).

4. W sprawie BB - AP pozwany wyraźnie odpowiedział na pytanie Sądu z 21.6.2005: „Nie zgłaszam nowych wniosków dowodowych”. Powódka całkowicie zignorowała sprawę w III Instancji (wyznaczonej przez Najwyższy Trybunał Sygnatury Apostolskiej na prośbę pozwanego). Trudno dostrzec, jakie „dokumenty" miałby był chcieć oglądać pozwany, i co ma na myśli pisząc teraz o ,braku wglądu w akta sprawy”. W wyroku tut. Sądu wyraźnie napisano, że „w III Instancji nie poszerzono ani nie pogłębiono materiału dowodowego", w odpowiedzi na zapytanie z 9.4.br. poinformowano skarżącego, że ,,akta III Instancji nie zawierają niczego, co stronom nie jest jeszcze znane". O stanie sprawy (skład Trybunału, przedmiot sporu...) strony zostały poinformowane.

5. Wywody skarżącego się nie tylko kanonicznie bezpodstawne, lecz także niegodne. Skarżący przyznaje, że argumenty, na które się powołuje, mają ,charakter ściśle formalny”. Niezależnie od faktu, że to właśnie wskutek stanowiska skarżącego, który poinformował Sąd, że nie zgłasza nowych wniosków dowodowych, brak w aktach III Instancji „dokumentu do okazania stronie” (chyba że chodziłoby o „okazanie" mu jego własnego pisma), sposób argumentowania powoda jest w procesie kanonicznym nie do przyjęcia. Nie mając argumentów rzeczowych usiłuje znaleźć przepis, który dałby się wykorzystać dla własnych korzyści. W praktyce sądowej nazywa się to „wynajdywaniem różnych kruczków”. Taki „formalizm prawny”, czy to na korzyść strony procesowej, czy to na jej niekorzyść, był wielokrotnie potępiany w przemówieniach papieskich do Roty Rzymskiej (np. przem. Piusa XII z 1.10.1942 - AAS 1942, 341). Doniosłość przedmiotu procesu o nieważność małżeństwa (ważność sakramentu!) powinna powstrzymywać od sięgania po argumenty pozorowane.

6. Skarżący przyznaje dwukrotnie, że jego żądanie ma na celu „umożliwienie złożenia nowych wniosków dowodowych”, ,przedstawienie prośby o uzupełnienie materiału dowodowego". Skoro skarżący w 2005 r. nie zgłaszał nowych wniosków dowodowych, a teraz uważa, że takimi dysponuje, mógł (i może) postapić zgodnie z pouczeniem zawartym w piśmie z 20.10.2005 notyfikującym wyrok. Napisano tam: „Gdyby istniały natomiast nowe, nierozpatrywane dotychczas dowody, 
można zwrócić się do Trybunału Roty Rzymskiej z prośbą o nowe rozpatrzenie sprawy wzgl. wnieść do Najwyższego Trybunału Sygnatury Apostolskiej o wyznaczenie do takiego rozpatrzenia kolejnego Sądu kościelnego w Polsce". Taki sposób postępowania, przewidziany przez prawo (kan. 1644 §1) jako nadzwyczajny środek wyświetlenia prawdy, stoi przed skarżącym otworem. Skarga o nieważność wyroku nie jest środkiem dopuszczonym przez prawo do przedkładania dowodów nieznanych lub zaniedbanych w trakcie procesu.

7. Kosztami postępowania obciąża się skarżącego.

8. Od powyższej decyzji przysługuje prawo odwołania według właściwości wskazanej w p.6. 